\title{
PERANCANGAN SISTEM MONITORING TEGANGAN, ARUS DAN FREKUENSI PADA PEMBANGKIT LISTRIK TENAGA MIKROHIDRO BERBASIS IOT
}

\author{
Muhammad Zaini', \\ Program Studi Teknik Elektro Universitas Nurul Jadid \\ Email: zaini241@gmail.com \\ Safrudin ${ }^{1}$ \\ Program Studi Teknik Elektro Universitas Nurul Jadid \\ Email: safrudin89@gmail.com \\ Moh. Bachrudin ${ }^{1}$ \\ Program Studi Teknik Elektro Universitas Nurul Jadid \\ Email: udintf06@gmail.com
}

\begin{abstract}
S : The development renewable energy uses is increasing, including micro-hydro power plants. A micro hydro power plant technically works by utilizing the height of the water fall, water discharge and water pressure. This energy is converted into mechanical energy by rotating the turbine shaft, after which the mechanical energy on the turbine shaft is transferred to the transmission and then connected to a generator to be converted into electrical energy. Due to the power losses created and the time factor, a micro hydro power plant needs regular checking or monitoring. However, conventional micro hydro power plants are still checked manually. So from the above problems, research was carried out in the form of designing a monitoring system for voltage, current and frequency in micro-hydro power plants based on the Internet of Things (IoT). From the monitoring of voltage, current and frequency, it is hoped that the actions will be taken and when the maintenance will be carried out. This design is done by designing software and hardware. Hardware includes the ESP32 microcontroller board which is used to read and process voltage, current and frequency sensor data from the PZEM-004T $v 3$ sensor module and remotely control solid state relay (SSR relay). Then, software design such as the Internet of Things (IoT) is carried out using the Ubidots platform and connected to the internet via a Wi-Fi connection for monitoring and notification via Telegram messages. In the monitoring system testing, notification and control of SSR relays were obtained from the results of sending data to Ubidots and the success of sending SSR relay notifications and controls. Data transmission, notification and SSR relay control has a $100 \%$ success.
\end{abstract}

Keyword: Internet of Things (IoT); SSR relay; PZEM-004T v3; PLTMH; Ubidots

ABSTRAK: Perkembangan pemanfaatan energi baru dan terbarukan semakin meningkat, di antaranya pembangkit listrik tenaga mikrohidro. Pembangkit listrik tenaga mikrohidro secara teknik bekerja dengan memanfaatkan ketinggian jatuh air, debit air dan tekanan air. Dari energi tersebut diubah menjadi energi mekanik dengan memutar poros turbin, setelahnya energi mekanik pada poros turbin ditransfer menuju transmisi kemudian disambungkan dengan generator untuk kemudian diubah menjadi energi listrik. Karena adanya rugirugi daya yang tercipta dan faktor waktu, pembangkit listrik tenaga mikrohidro dibutuhkan pengecekan atau monitoring secara berkala. Namun pada pembangkit listrik tenaga mikrohidro konvensional masih dilakukan pengecekan secara manual. Maka dari permasalahan diatas dilakukanlah penelitian berupa perancangan sistem monitoring tegangan, arus dan frekuensi pada pembangkit listrik tenaga mikrohidro berbasis Internet of Things (IoT). Dari pemantauan tegangan, arus dan frekuensi tadi diharapkan mampu dianalisis tindakan apa yang akan dilakukan dan kapan akan dilakukan perawatan. Perancangan ini dilakukan dengan merancang perangkat lunak dan perangkat keras. Perangkat keras di antaranya board mikrokontroler ESP32 yang digunakan untuk membaca dan mengolah data sensor tegangan, arus dan frekuensi dari modul sensor PZEM-004T v3 dan mengontrol solid state relay (SSR relay) secara jarak jauh. Kemudian dilakukan perancangan perangkat lunak seperti Internet of Things (IoT) dengan menggunakan platform Ubidots dan dihubungakan ke internet melalui koneksi Wi-Fi guna monitoring dan notifikasi melalui pesan Telegram. Pada pengujian sistem monitoring, notifikasi dan kontrol SSR relay didapatkan dari hasil pengiriman data ke Ubidots dan keberhasilan pengiriman notifikasi dan kontrol SSR relay. Pengiriman data, notifikasi dan kontrol SSR relay memiliki keberhasilan sebesar $100 \%$.

Kata Kunci: Internet of Things (IoT); SSR relay; PZEM-004T v3; PLTMH; Ubidots

\section{PENDAHULUAN}

Perk erkembangan pemanfaatan energi baru dan terbarukan bertambah tahun semakin meningkat, salah satu di antaranya ialah pembangkit listrik tenaga mikrohidro. Data dari Kementerian Energi dan Sumber Daya Mineral menyebutkan potensi pemanfaatan tenaga air di Indonesia sangat tinggi, yakni 75.000 megawatt (MW). Namun pemanfaatannya masih terealisasi sebesar 10,1\% atau 7.500 megawatt dari seluruh potensi yang ada [1]. Pembangkit listrik tenaga mikrohidro merupakan pembangkit berskala kecil, daya yang dihasilkan kurang dari 200kw. Pembangkit listrik tenaga mikrohidro merupakan salah satu pemanfaatan energi baru dan terbarukan yang memiliki emisi atau dampak buruk terhadap lingkungan yang kecil. Pembangkit listrik tenaga mikrohidro memiliki kontruksi, biaya perawatan dan suku cadang yang relatif murah dari segi ekonomi dan mampu diterima baik oleh masyarakat [2]

1 Universitas Nurul Jadid, Karanganyar, Kecamatan Paiton, Kabupaten Probolinggo, Jawa Timur 67292 
Pembangkit listrik tenaga mikrohidro secara teknik bekerja dengan memanfaatkan ketinggian jatuh air, debit dan tekanan air. Energi potensial air jatuh dari ketinggian yang berbeda dan memiliki debit serta tekanan diubah menjadi energi mekanik dengan menggerakkan poros pada turbin kincir. Poros turbin kincir disambung dengan rotor generator sehingga rotor mendapatkan energi mekanik dari poros turbin untuk kemudian dikonversi menjadi energi listrik oleh generator. Pembangkit listrik tenaga mikrohidro sangat berpotensi dan bermanfaat dibangun pada dataran tinggi atau daerah pegunungan, karena pada daerah-daerah tersebut memiliki ketersediaan air yang melimpah dan perbedaan ketinggian. Pembangkit listrik tenaga mikrohidro konvensional membutuhkan pengecekan atau pemantauan tegangan, arus dan frekuensi secara berkala guna mengambil tindakan untuk melakukan perawatan dalam waktu tertentu. Pengecekan atau monitoring yang dilakukan di pembangkit listrik tenaga mikrohidro pada umumnya masih secara manual, yakni mengunjungi pembangkit listrik tenaga mikrohidro dan melakukan pengecekan langsung yang membutuhkan waktu dan tenaga lebih untuk melakukannya. Selain itu pemutusan distribusi antara mikrohidro dengan beban/pengguna masih dilakukan secara manual, pemutusan ini harus dilakukan untuk menghindari kerusakan peralatan elektronik saat terjadi kenaikan/penuruan secara tiba-tiba atau bertahap pada referensi tegangan, arus atau frekuensi listrik yang dihasilkan mikrohidro. Dari uraian tersebut, dibutuhkan monitoring dan controlling secara cepat, tepat serta dapat diakses dari mana saja dan kapan saja dengan memanfaatkan perkembangan jaringan internet, salah satu konsep dari internet ialah Internet of Things atau biasa disingkat IoT. Internet of Things (IoT) merupakan konsep pengembangan dari internet, di mana sistemsistem fisik (Hardware) dalam hal ini ialah mikrokontroler dihubungkan dengan jaringan internet [3].

Mikrokontroler merupakan sebuah alat pengontrolan berskala kecil dan merupakan satu sistem komputer yang pada hakikatnya sebagian besar elemennya dikemas dalam satu Integrated Circuit (IC) dan menjadi bagian dari sebuah embedded system (sistem yang didesain untuk melakukan satu atau lebih fungsi khusus secara real time) [4]. Dengan demikian, konsep IoT dapat diterapkan dalam merancang suatu alat yang berfungsi untuk membaca tegangan, arus dan frekuensi menggunakan sebuah sensor, kemudian data yang diterima oleh sensor diteruskan ke mikrokontroler untuk diolah menjadi sebuah data yang dapat dikirimkan melalui internet guna ditampilkan dalam sebuah website guna monitoring dan melakukan kontrol secara realtime, jarak jauh dan cepat. Sehingga diangkatlah penelitian berjudul, "Perancangan Sistem Monitoring Tegangan, Arus dan Frekuensi pada Pembangkit Listrik Tenaga Mikrohidro Berbasis IoT".

\section{METODOLOGI}

Pada penelitian ini digunakan model pengembangan Prototipe. Model pengembangan ini mudah dipahami dan mempunyai tahapan yang sederhana, sehingga prosedur pengembangan sistem yang akan dibuat menjadi lebih jelas pada tiap tahapannya.

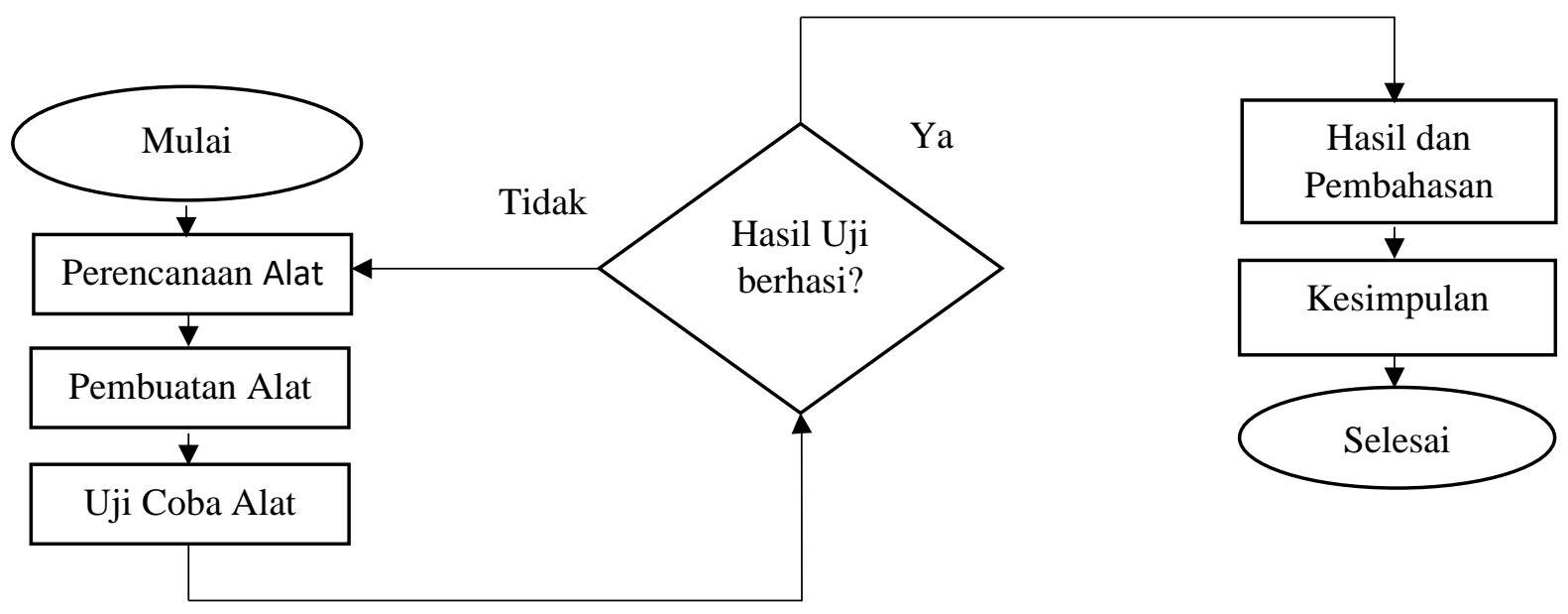

- Gambar 1. Diagram Alir Penelitian 


\section{Studi Literatur}

Melakukan Kajian teori dengan membaca jurnal-jurnal relevan terdahulu, buku dan penelusuran daring sebagai acuan referensi dalam melakukan penelitian dan perancangan serta pengembangan guna mempermudah dan bisa mengembangkan penelitian sebelumnya, sehingga diharapkan mampu memberi hasil yang lebih baik dan bermanfaat.

2. Perencanaan Alat

a. Modul Sensor PZEM-004t v3

Modul PZEM-004T adalah sebuah modul sensor multifungsi yang berfungsi untuk mengukur daya, tegangan, arus dan energi yang terdapat pada sebuah aliran listrik. Modul ini sudah dilengkapi sensor tegangan dan sensor arus (CT) yang sudah terintegrasi [5]

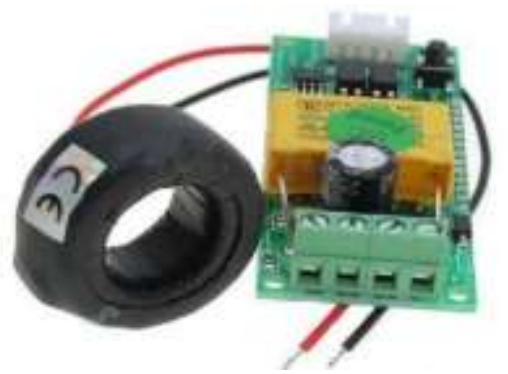

Gambar 2. Modul Sensor PZEM-004t v3

Modul sensor ini memiliki rentang pengukuran tegangan sebesar 80-260 VAC dengan resolusi pengukuran 0,1 VAC serta keakuratan pembacaan sebesar $0,5 \%$. Arus kerja pada modul sensor ini memiliki rentang pengukuran sebesar 0-100A dengan pembacaan awal senilai 0,02A. Modul sensor ini juga memiliki resolusi pembacaan sebesar 0,001A dengan keakuratan sebesar 0,5\%. Pembacaan rentang frekuensi pengukuran frekuensi pada modul sensor ini sebesar $45-65 \mathrm{~Hz}$ dengan resolusi sebesar $0,1 \mathrm{~Hz}$ dengan keakuratan pembacaan sebesar 0,5\% [6].

b. Mikrokontroler ESP32 Board

Merupakan board mikrokontroler yang memiliki chip $2,4 \mathrm{GHz} W i-F i$, selain itu board ini dilengkapi dengan bluetooth yang dirancang dengan TSMC ultra-daya rendah (Espressif, 2020). Board ini dikenalkan oleh Espressif System yang merupakan penerus dari board sebelumnya yakni ESP8266. Board ini memiliki beberapa keunggulan di antaranya memiliki daya pemakaian rendah, memiliki modul Wi-Fi yang sudah terintegrasi, serta memiliki bluetooth mode ganda dengan daya pemakaian rendah. Board ini kompatibel dengan teknologi Internet of Things (IoT) [7].

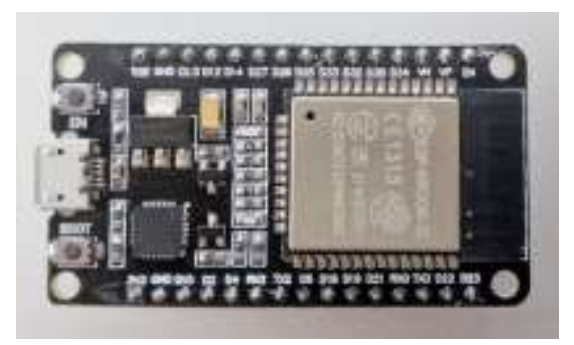

Gambar 3. ESP32 Board

Tabel 1. Spesifikasi ESP32 Board

\begin{tabular}{|c|c|}
\hline Atribut & Detail \\
\hline CPU & Tensilica Xtensa LX6 32bit Dual-Core di $160 / 240 \mathrm{MHz}$ \\
\hline SRAM & $520 \mathrm{~KB}$ \\
\hline FLASH & $2 \mathrm{MB}$ \\
\hline Tegangan & $2.2-3.6 \mathrm{Vdc}$ \\
\hline Arus Kerja & rata-rata $80 \mathrm{~mA}$ \\
\hline
\end{tabular}




\begin{tabular}{|c|c|}
\hline Dapat diprogram & Ya $(\mathrm{C}, \mathrm{C}++$, Python, Lua $)$ \\
\hline Open Source & Ya \\
\hline \multicolumn{2}{|c|}{ Pin I/O } \\
\hline GPIO & 32 \\
\hline SPI & 4 \\
\hline I2C & 2 \\
\hline PWM & 8 \\
\hline ADC & $18(12-b i t)$ \\
\hline DAC & $2(8-b i t)$ \\
\hline & Konektivitas \\
\hline Wi-Fi & $802.11 \mathrm{~b} / \mathrm{g} / \mathrm{n}$ \\
\hline Bluetooth & 4.2 BR/EDR+BLE \\
\hline UART & 3 \\
\hline
\end{tabular}

\section{c. Solid State Relay (SSR Relay)}

Solid state relay (SSR Relay) merupakan teknologi relay terbaru dimana relay ini tidak memiliki kontak yang bergerak seperti pendahulunya. Dalam pengoperasiannya, SSR relay tidak jauh berbeda dari relay mekanis yang memiliki kontak bergerak. SSR relay ini menggunakan teknologi switching semikonduktor, seperti thyristor, triac, dioda dan transistor [8].

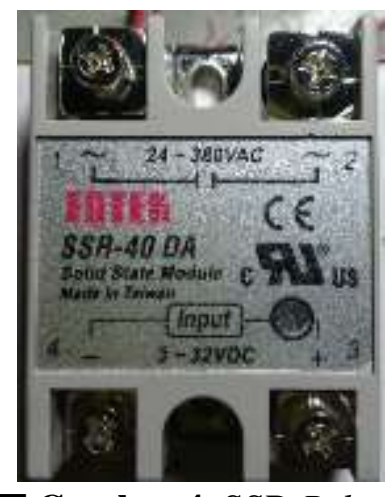

\section{d. Platform Ubidots}

Gambar 4. SSR Relay

Ubidots merupakan platform dari Internet of Things (IoT) yang dapat mengelola perangkat secara bersamaan kemudian disimpan dalam bentuk data serta menampilkannya dalam bentuk grafik dimana data yang diterima berasal dari parameter sensor pada mikrokontroler dan disimpan pada penyimpanan cloud di Ubidots [9]. Ubidots dapat menkonfigurasi berupa tindakan dan notifikasi dalam bentuk alert berdasarkan data realtime. Ubidots memiliki fitur application programming interface (API) yang memungkinkan mikrokontroler yang terkoneksi internet dapat membaca dan menulis data ke Ubidots pada tiap-tiap fungsi fiturnya [10]

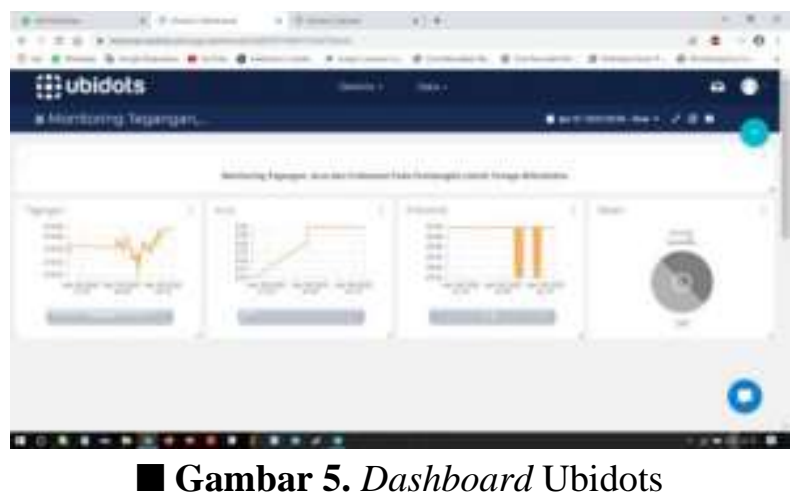




\section{e. Internet of Things (IoT)}

Internet of Things (IoT) merupakan salah satu bentuk pengembangan dari teknologi jaringan internet. IoT dapat digambarkan sebagai hubungan dari berbagai perangkat pintar, komputer pribadi, sensor, aktuator maupun perangkat lain yang terhubung melalui jaringan internet sehingga dapat meghasilkan informasi yang dapat diakses dan digunakan oleh manusia maupun sistem lainnya. IoT juga dapat diartikan sebagai suatu konsep dengan menempatkan objek-objek fisik yang dapat terkoneksi dengan jaringan internet, serta mampu mengidentifikasikan secara otomatis melalui perangkat lainnya. Teknologi IoT dapat diterapkan untuk kebutuhan monitoring, kontrol dan otomatisasi [11].

3. Desain dan Pembuatan Alat

a. Diagram Blok

Diagram blok fungsional sistem yang dibuat pada perancangan penelitian ini secara umum dapat dilihat pada gambar berikut:

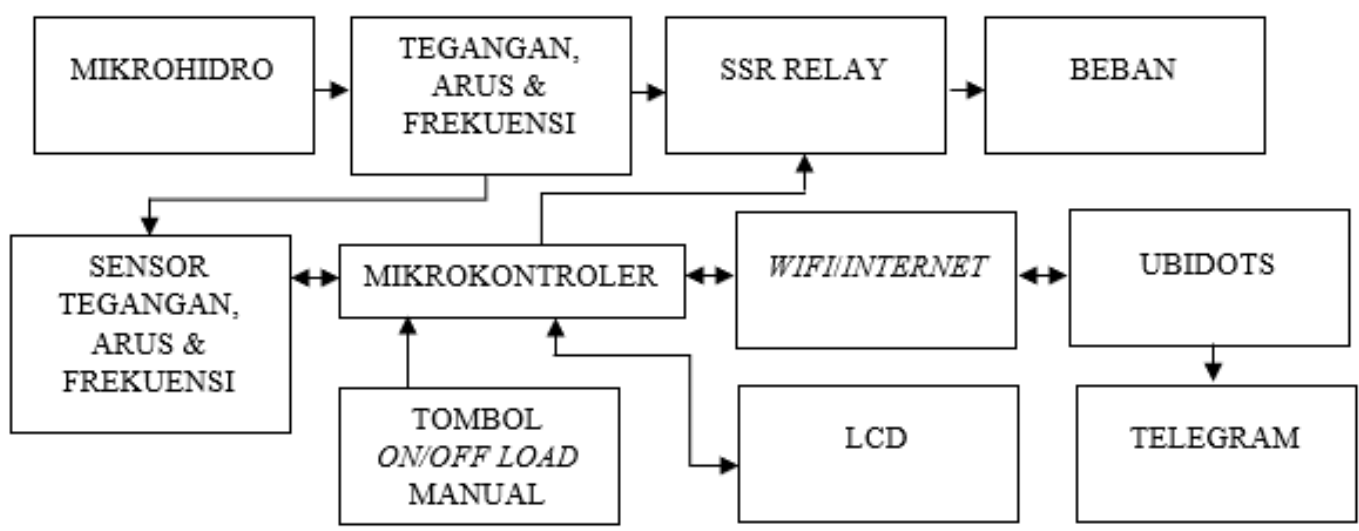

Gambar 6. Diagram Blok Fungsional

Besaran tegangan, arus dan frekuensi yang ada pada generator di pembangkit listrik tenaga mikrohidro dibaca oleh modul sensor PZEM-004t v3 kemudian diubah ke dalam data yang kemudian diolah oleh mikrokontroler ESP32. Data yang sudah diolah kemudian dikirim ke database Ubidots melalui internet menggunakan koneksi Wi-Fi yang sudah tertanam di board mikrokontroler ESP32 untuk kemudian diolah ke dalam tampilan yang bisa disesuaikan oleh pengguna di halaman Ubidots.

b. Wiring Keseluruhan

Perancangan wiring sistem adalah perancangan penyambungan hardware secara keseluruhan yang meliputi perancangan wiring sensor tegangan, arus dan frekuensi (PZEM-004T $\mathrm{v} 3$ ), perancangan wiring LCD, perancangan wiring solid state relay (SSR Relay), perancangan wiring tombol on/off load manual, perancangan wiring relay module dan perancangan wiring tombol reboot.

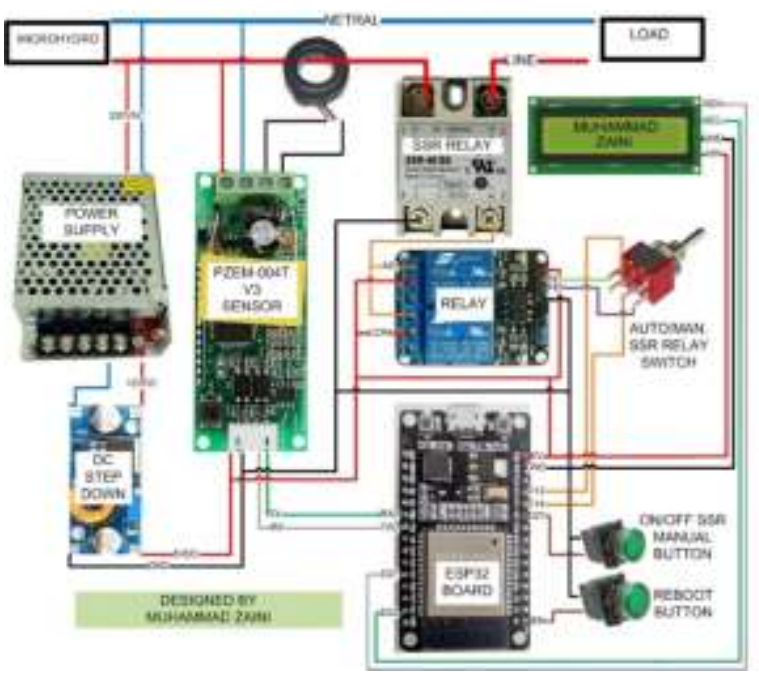

Gambar 7. Wiring Keseluruhan 
c. Perancangan Tampilan Monitoring Pada Ubidots

Perancangan ini sebagai media interface antara alat dengan operator/user untuk monitoring serta melakukan kontrol dari jarak jauh dengan penghubung internet. Platform yang digunakan ialah Ubidots. Mulai dari membuat akun di website Ubidots hingga menyesuaikan tampilan sesuai yang diinginkan. Berikut merupakan tampilan awal dari Ubidots:

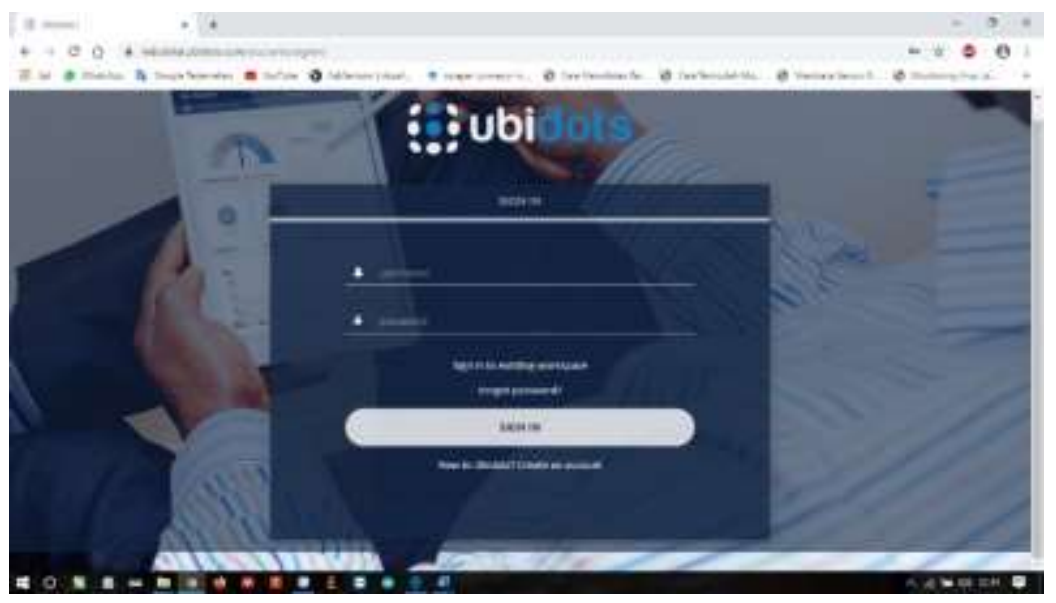

Gambar 8. Halaman Awal Ubidots

d. Perancangan Notifikasi/Alert via Telegram pada Ubidots

Ubidots memiliki fitur events yang dapat difungsikan menjadi notifikasi atau alert dalam bentuk kiriman e-mail, Telegram, short message servise (sms) dan panggilan telfon. Notifikasi ini akan dikirim dalam keadaan tertentu sebagaimana konfigurasinya. Untuk melakukan konfigurasi ini bisa dengan mengklik events pada menu bar data di halaman dashboard. Klik create events untuk membuat baru. Setelah itu pilih variable yang akan diatur dengan kondisi dan waktu tertentu terlihat pada Gambar 9.

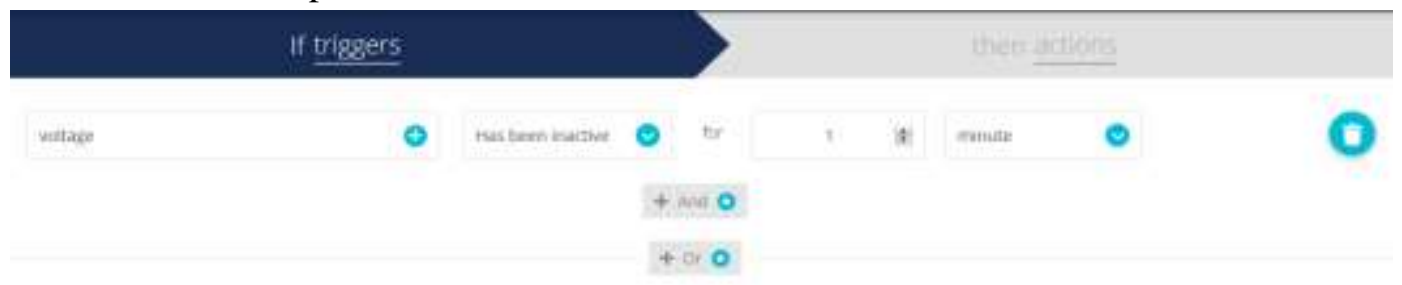

Gambar 9. Konfigurasi Kondisi Untuk Notifikasi via Telegram

Setelah melakukan konfigurasi jenis variable, kondisi dan waktu, selanjutnya klik panah kanan untuk memilih send Telegram untuk mengirim notifikasi/alert dalam bentuk pesan Telegram. Selanjutnya memilih hari dan jam kapan events tersebut akan aktif. Setelah selesai klik centang untuk finish. Notifikasi akan dikirimkan jika memenuhi logika yang telah dikonfigurasikan.

\section{HASIL DAN PEMBAHASAN}

Pada penelitian ini untuk mengetahui kinerja dari perancangan alat dan pembuatan sistem yang telah dirancang sebelumnya, maka diperlukan pengujian dan pembahasan dari setiap komponen yang dirancang agar dapat berjalan dengan baik dan sesuai dengan yang diharapkan. Adapun realisasi alat pada penelitian ini dapat dilihat pada gambar 10 dan gambar 11, serta realisasi alat secara real pada gambar 12. Ukuran box panel yang dipakai memiliki dimensi $25 \times 35 \times 15 \mathrm{~cm}$. 


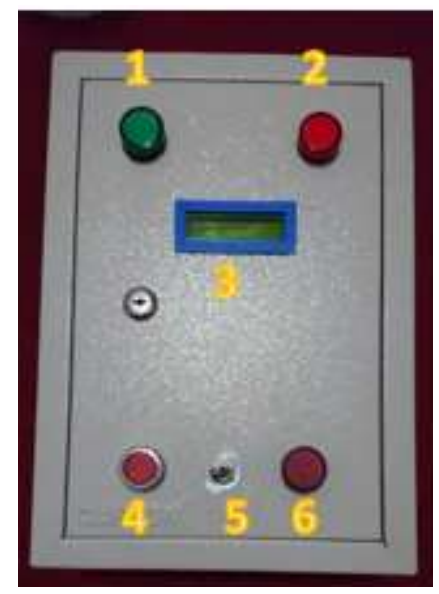

eterangan :

- Gambar 10. Hasil Alat Tampak Luar

1. Pilot lamp atau lampu indikator pembangkit listrik tenaga mikrohidro

2. Pilot lamp atau lampu indikator beban/pemakai/load

3. Liquid crystal display

4. Pushbutton/tombol on/off load manual

5. Double pole double throw (DPDT Switch)

6. Push button reboot/restart system

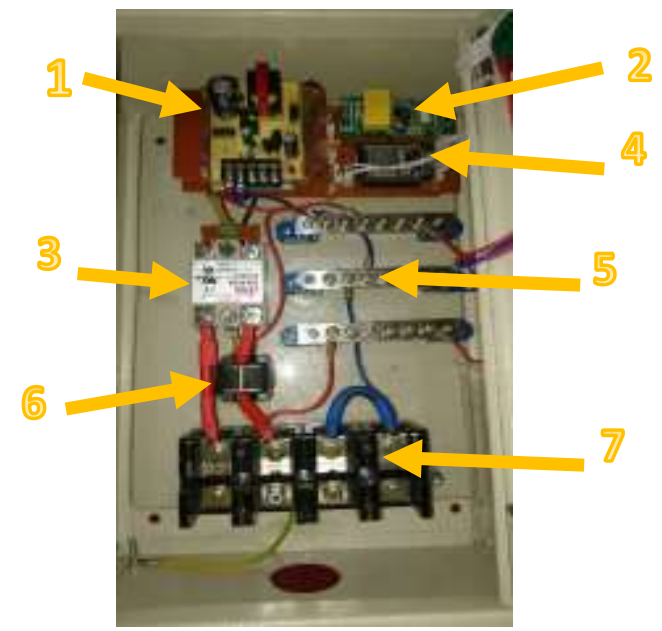

Gambar 11. Hasil Alat Tampak Dalam

Keterangan :

1. Power supply, stepdown, relay module 2 channel

2. Sensor tegangan, arus dan frekuensi (modul pzem-004t v3)

3. Solid state relay (relay ssr)

4. ESP32 board

5. Busbar

6. Coil sensor arus

7. Terminal 100A $4 p$ 


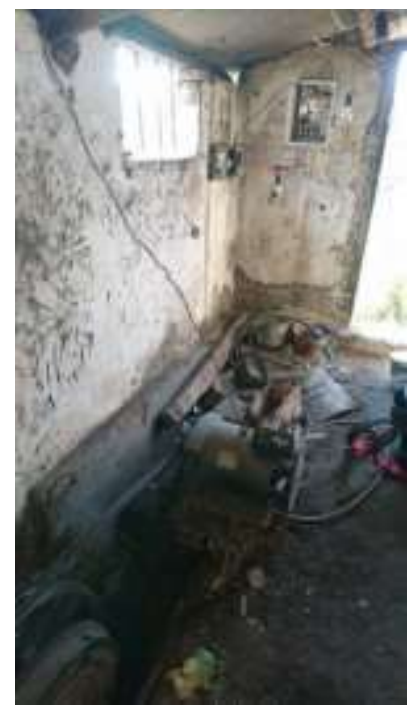

Keterangan :

Gambar 12. Realisasi Alat Secara Real

Alat dipasang dengan menempelkan pada tembok rumahan pembangkit listrik tenaga mikrohidro di desa Blado Wetan, kecamatan Banyuanyar kabupaten Probolinggo, Jawa Timur. Pembangkit ini digunakan mulai jam 16.00-07.00 untuk memasok kebutuhan listrik pondok pesantren Nahdlatut Thalibin yang berada tidak jauh dari pembangkit listrik tenaga mikrohidro.

\section{Hasil Pengujian Modul Sensor PZEM-004t v3}

Pengujian ini bertujuan untuk mengukur kemampuan dan ketelitian modul sensor dengan parameter pembacaan ialah tegangan, arus dan frekuensi listrik. Pada pengujian ini dilakukan dengan membandingkan hasil pembacaan modul sensor yang ditampilkan pada platform Ubidots dan multimeter.

Tabel 2. Hasil Pengujian Pembacaan Tegangan

\begin{tabular}{|c|c|c|c|c|}
\hline \multirow{2}{*}{ NO } & \multicolumn{2}{|c|}{ Hasil Pembacaan Tegangan (VAC) } & \multirow{2}{*}{ Selisih } & \multirow{2}{*}{ error(\%) } \\
\cline { 2 - 3 } & PZEM-004T & Multimeter & & 1,84 \\
\hline 1 & 170,70 & 173,9 & 3,2 & 0,4 \\
\hline 2 & 199,25 & 198,3 & 0,95 & 0,25 \\
\hline 3 & 187,52 & 188,0 & 0,48 & 0,13 \\
\hline 4 & 207,53 & 207,8 & 0,27 & 1,76 \\
\hline 5 & 103,29 & 101,5 & 1,79 & 0,8 \\
\hline \multicolumn{3}{|c|}{ rata-rata } \\
\hline
\end{tabular}

- Tabel 3. Hasil Pengujian Pembacaan Arus

\begin{tabular}{|c|c|c|c|c|}
\hline \multirow{2}{*}{ NO } & \multicolumn{2}{|c|}{ Hasil Pembacaan Arus (I) } & \multirow{2}{*}{ Selisih } & \multirow{2}{*}{ error(\%) } \\
\cline { 2 - 3 } & PZEM-004T & Multimeter & & 2,3 \\
\hline 1 & 2,95 & 3,02 & 0,07 & 0,1 \\
\hline 2 & 3,04 & 3,5 & 0,46 & 4,3 \\
\hline 3 & 3,35 & 3,21 & 0,14 & 5,9 \\
\hline 4 & 2,52 & 2,68 & 0,16 & 8,3 \\
\hline 5 & 3,42 & 3,73 & 0,31 & 4,18 \\
\hline \multicolumn{3}{|c|}{ rata-rata } \\
\hline
\end{tabular}


- Tabel 4. Hasil Pengujian Pembacaan Frekuensi

\begin{tabular}{|c|c|c|c|c|}
\hline \multirow{2}{*}{ NO } & \multicolumn{2}{|c|}{ Hasil Pembacaan Frekuensi (Hz) } & \multirow{2}{*}{ Selisih } & \multirow{2}{*}{ error(\%) } \\
\cline { 2 - 3 } & PZEM-004T & Multimeter & & 1,2 \\
\hline 1 & 46,4 & 47 & 0,6 & 0 \\
\hline 2 & 51 & 51 & 0 & 2,3 \\
\hline 3 & 48,1 & 47 & 1,1 & 0,7 \\
\hline 4 & 53,6 & 54 & 0,4 & 1,2 \\
\hline 5 & 32,6 & 34 & 1,4 & 1,08 \\
\hline \multicolumn{3}{|c|}{ rata-rata } \\
\hline
\end{tabular}

Dari data pada tabel 4.1, tabel 4.2 dan tabel 4.3 dapat diketahui hasil pengujian pembacaan modul sensor PZEM-004T v3 dan multimeter. Kemudian dapat ditarik jumlah besaran nilai error dari selisih pembacaan. Persentase error didapatkan dari pembagian nilai selisih pembacaan dengan nilai multimeter dan dikalikan $100 \%$.

$$
\text { Error }(\%)=\frac{\text { selisih nilai pembacaan }}{\text { nilai multimeter } / \text { avo }} \times 100 \%
$$

\section{Hasil Pengujian Solid State Relay (SSR Relay)}

Pengujian relay ini bertujuan untuk mengetahui apakah berfungsi atau tidak. Pengujian ini dilakukan dengan cara memberi tegangan kerja pada input signal SSR relay, yakni 3-32 vdc. Sehingga diharapkan dapat diketahui apakah relay berfungsi baik atau tidak.

Tabel 5. Hasil Pengujian SSR Relay Secara Offline

\begin{tabular}{|c|c|c|c|}
\hline Pengujian ke- & Besar Tegangan (vdc) & Kondisi Relay & Keterangan \\
\hline 1 & 0 & OFF & Baik \\
\hline 2 & 1 & OFF & Baik \\
\hline 3 & 2 & OFF & Baik \\
\hline 4 & 3 & ON & Baik \\
\hline 5 & 4 & ON & Baik \\
\hline 6 & 5 & ON & Baik \\
\hline 7 & 6 & ON & Baik \\
\hline 8 & 7 & ON & Baik \\
\hline 9 & 8 & ON & Baik \\
\hline 10 & 9 & ON & Baik \\
\hline
\end{tabular}

Dari data tabel 5 dapat disimpulkan bahwa SSR relay dapat bekerja dengan baik. Setelah melakukan pengujian SSR relay secara offline maka dilakukan pengujian SSR Relay secara online yakni dengan mengontrol dari Ubidot, adapun hasil pengujian seperti berikut. 
Tabel 6. Hasil Pengujian SSR Relay Secara Online

\begin{tabular}{|c|c|c|c|c|}
\hline Pengujian ke- & $\begin{array}{c}\text { Nilai dari } \\
\text { Ubidots }\end{array}$ & Kondisi Relay & Keterangan & Delay(S) \\
\hline 1 & 0 & OFF & Baik & 3 \\
\hline 2 & 1 & OFF & Baik & 3 \\
\hline 3 & 2 & OFF & Baik & 4 \\
\hline 4 & 3 & ON & Baik & 4 \\
\hline 5 & 4 & ON & Baik & 3 \\
\hline 6 & 5 & ON & Baik & 3 \\
\hline 7 & 6 & ON & Baik & 3 \\
\hline 8 & 7 & ON & Baik & 3 \\
\hline 9 & 8 & ON & Baik & 4 \\
\hline 10 & 9 & ON & Baik & 4 \\
\hline
\end{tabular}

Dari tabel 6 dapat diketahui bahwa pengontrolan SSR relay secara online dan jarak jauh bekerja dengan baik dan memiliki rata-rata delay 3,5 detik.

3. Hasil Pengujian Data Monitoring Pada Ubidots

Pengujian platform Ubidots dilakukan dengan mengirim dan monitoring data hasil pembacaan modul sensor PZEM-004T v3 yang diterima dari mikrokontroler melalui internet of things (IoT) pada website Ubidots. Nilai pembacaan akan terus diperbarui secara real time. Pengujian ini bertujuan untuk mengetahui apakah perangkat keras telah terintegrasi dengan platform Ubidots dengan baik atau tidak.

- Tabel 7. Data Hasil Monitoring

\begin{tabular}{|c|c|c|c|c|c|}
\hline \multirow{2}{*}{ NO } & \multicolumn{2}{|c|}{ Waktu } & \multicolumn{3}{c|}{ Hasil } \\
\cline { 2 - 6 } & Tanggal & Jam & Tegangan & Arus & Frekuensi \\
\hline 1 & $22 / 06 / 2020$ & 17.22 & 170,70 & 2,95 & 46,4 \\
\hline 2 & $22 / 06 / 2020$ & 20.34 & 199,25 & 3,04 & 51 \\
\hline 3 & $22 / 06 / 2020$ & 21.50 & 187,52 & 3,35 & 48,1 \\
\hline 4 & $23 / 06 / 2020$ & 01.14 & 207,53 & 2,52 & 53,6 \\
\hline 5 & $23 / 06 / 2020$ & 19.09 & 103,29 & 3,42 & 32,6 \\
\hline 6 & $23 / 06 / 2020$ & 22.11 & 175 & 3,17 & 46,5 \\
\hline 7 & $24 / 06 / 2020$ & 04.11 & 205,34 & 2,02 & 52,8 \\
\hline 8 & $24 / 06 / 2020$ & 20.19 & 103,68 & 3,61 & 33 \\
\hline 9 & $24 / 06 / 2020$ & 22.54 & 114,21 & 3,67 & 34,7 \\
\hline 10 & $25 / 06 / 2020$ & 00.47 & 200,6 & 2,44 & 52,6 \\
\hline 11 & $25 / 06 / 2020$ & 16.29 & 192 & 2,07 & 50 \\
\hline 12 & $25 / 06 / 2020$ & 22.40 & 141,1 & 3,12 & 40,6 \\
\hline
\end{tabular}

Dari tabel 7 diketahui hasil monitoring tegangan, arus dan frekuensi dengan jumlah pengambilan data tiga kali dalam 3 hari berturut-turut.

4. Hasil Pengujian Tampilan Halaman Monitoring pada Ubidots

Pengujian tampilan pada web Ubidots bertujuan untuk mengetahui data sensor dalam tampilan grafik serta mengetahui kerja infrastruktur pada Ubidots telah berfungsi baik atau tidak. Pengujian ini dilakukan dengan menampilkan hasil data pembacaan sensor yang diterima Ubidots. 


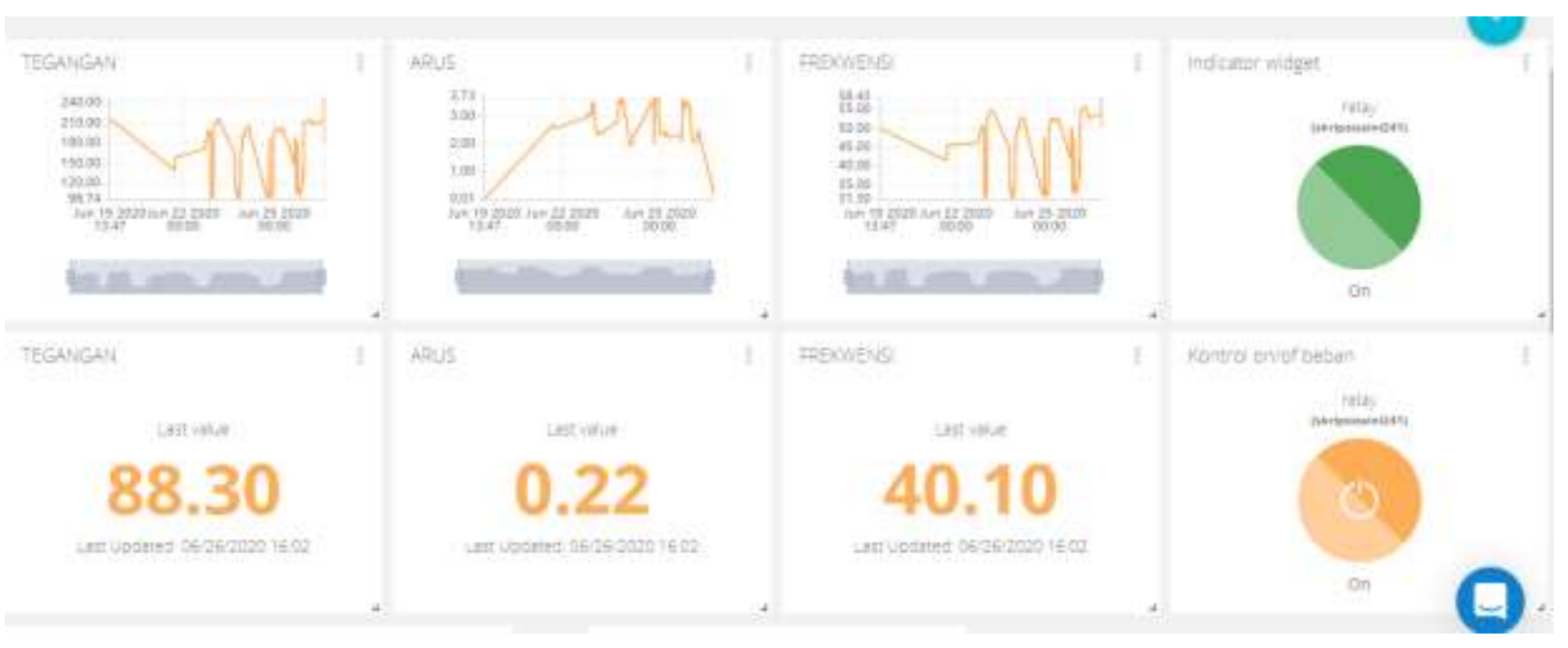

Gambar 13. Hasil Tampilan Monitoring pada Ubidots

\section{Hasil Pengujian Notifikasi via Telegram}

Pengujian ini bertujuan untuk mengetahui apakah pengiriman notifikasi berupa pesan Telegram telah berjalan baik atau tidak. Pengujian ini dilakukan dengan mengatur kondisi pengiriman notifikasi pada fitur event di platform Ubidots. Pesan Telegram akan dikirimkan dengan kondisi pembangkit listrik tenaga mikrohidro keadaan berhenti beroperasi dan saat alat kehilangan komunikasi secara realtime dengan Ubidots karena kendala koneksi jaringan internet.

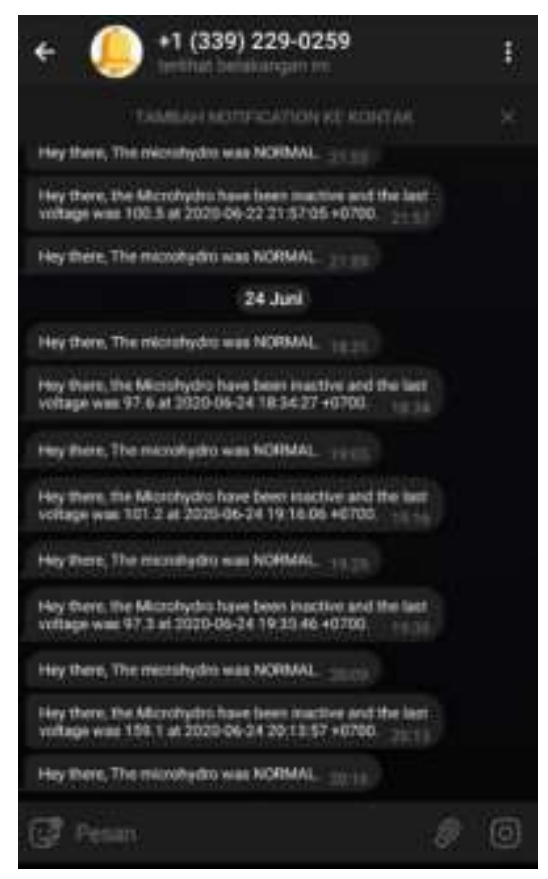

Gambar 14. Tampilan Notifikasi Melalui Pesan Telegram

Pada gambar 14 dapat diketahui bahwa Ubidots berhasil mengirim notifikasi melalui pesan Telegram. Notifikasi ini dikirim saat memenuhi kondisi yang telah ditentukan. Sehingga pengiriman notifikasi dengan kondisi yang telah ditentukan berhasil berjalan dengan baik.

\section{KESIMPULAN}

Setelah melakukan perancangan, perencanaan, pembuatan, pengujian dan pembahasan serta hasil perancangan sistem monitoring tegangan, arus dan frekuensi pada pembangkit listrik tenaga mikrohidro berbasis internet of things (IoT), maka diambil kesimpulan dan saran pada penelitian ini sebagai berikut: 1. Sistem monitoring tegangan, arus dan frekuensi pada pembangkit listrik tenaga mikrohidro berbasis Internet of Things (IoT) ini dapat me-monitoring dengan baik secara realtime. 
2. Selain monitoring juga dapat memutus dan menyambungkan (breaker control) beban dari pembangkit listrik tenaga mikrohidro jarak jauh serta memberikan notifikasi berupa pesan Telegram saat pembangkit listrik tenaga mikrohidro dalam keadaan mati atau saat alat kehilangan koneksi dengan Ubidots.

3. Dalam sistem monitoring di perancangan sistem monitoring tegangan, arus dan frekuensi pada pembangkit listrik tenaga mikrohidro berbasis Internet of Things (IoT) tidak dapat dilakukan monitoring apabila koneksi internet tidak ada.

4. Hasil pembacaan modul sensor PZEM-004T v3 pada alat ini memiliki tingkat keakuratan yang baik. Dimana nilai error rata-rata pembacaan tegangan sebesar $0,8 \%$, pembacaan arus sebesar $4,18 \%$ dan pembacaan frekuensi sebesar 1,08\% dengan masing-masing pengujian sebanyak 5 kali.

5. Pemutus beban dari pembangkit listrik tenaga mikrohidro berupa Solid State Relay (SSR relay) dapat bekerja dengan baik.

6. Respon SSR relay terhadap perintah jarak jauh cukup baik dengan delay kurang lebih 3 detik tergantung koneksi internet.

7. Notifikasi berupa alert dari fitur event pada Ubidots akan dikirim melalui pesan Telegram apabila memenuhi kondisi yang sudah di sesuaikan di halaman event pada Ubidot

\section{DAFTAR PUSTAKA}

[1] Kementerian Energi dan Sumber Daya Mineral, "Kebijakan Pengembangan Tenaga Air," Direktorat Jenderal Energi Baru, Terbarukan dan Konservasi Energi, 2014. [Online]. Available: http://ebtke.esdm.go.id/post/2014/07/02/628/kebijakan.pengembangan.tenaga.air. [Accessed: 13-Feb-2020].

[2] A. P. Damastuti, "Pembangkit Listrik Tenaga Mikrohidro," WACANA, vol. 7, no. 8, pp. 11-12, 1997.

[3] T. D. Hendrawati, Y. D. Wicaksono, and E. Andika, "Internet of Things: Sistem KontrolMonitoring Daya Perangkat Elektronika," JTERA (Jurnal Teknol. Rekayasa), vol. 3, no. 2, p. 177, 2018, doi: 10.31544/jtera.v3.i2.2018.177-184.

[4] J. Arifin, L. N. Zulita, and Hermawansyah, "Perancangan Murottal Otomatis Menggunakan Mikrokontroller Arduino Mega 2560," J. Media Infotama, vol. 12, no. 1, pp. 89-98, 2016.

[5] F. Nur, "Alat Monitoring Pemakaian Energi Listrik Berbasis Android Menggunakan Modul PZEM-004T,” Pros. Semin. Nas. Teknol. Elektro Terap. 2017, vol. 01, no. 01, pp. 157-162, 2017.

[6] innovatorsguru, "PZEM-004T V3.0 User Manual," 2019.

[7] biswas, shatadru bipasha, dan $\mathrm{m}$ tariq iqbal, "Solar water pumping system control using a low cost ESP32 microcontroller," IEEE Can. Conf. Electr. Comput. Eng., 2018.

[8] E. Carmelon, "Technical Explanation for Solid-state Relays," IEEE Trans. Ind. Electron. Control Instrum., vol. 3, no. 1, pp. 1-29, 2014.

[9] C.-D. I. Indonesia, "Perancangan prototype sistem monitoring komparasi jarak jauh sensor suhu menggunakan iot selama masa pandemik covid-19 di indonesia," Universitas Mercu Buana, 2020.

[10] Novi Ainur Riza, "Sistem Monitoring dan Notifikasi pada Prototipe KVARH Meter Berbasis Internet of Things ( IoT )," Institut Teknologi Sepuluh Nopember, 2017.

[11] N. Soedjarwanto, G. F. Nama, T. Elektro, F. Teknik, T. Informatika, and A. T. Distribusi, "Monitoring Arus , Tegangan dan Daya pada Transformator Distribusi 20 KV Menggunakan Teknologi Internet of Things," EECCIS, vol. 13, no. 3, pp. 128-133, 2019. 